\title{
The Acceptability of Teachers' Value Related Statements About Sustainable Development and Climate Change Among Non-Science and Science Major Students from Kosovo
}

\author{
Zeqir Veselaj ${ }^{1}$, Gregor Torkar ${ }^{2}$
}

\begin{abstract}
In this paper we identify teachers' value-laden statements about sustainable development and climate change that are (not) acceptable for pre-service students of preschool education (non-science majors) and student teachers of biology and chemistry (science majors) in their final year of university studies at the Faculty of Education University of Prishtina, Kosovo. Fifteen statements were provided and students had to choose among options "acceptable statement", "unacceptable statement" and "cannot decide". The questionnaire was completed by 63 students. The results show that the students expect their teachers to promote the principles of sustainable development. The majority of students considered as unacceptable any teacher's statement that would throw doubt about the cause or necessity to act against climate change. Most of the students reported that they already heard unacceptable value-laden statements made by their teacher. Their most common reaction was to become alerted and discuss the statement with a colleague(s) in the classroom. Findings of the study do not provide clear conclusions on how science education of science and non-science major students influence on their acceptance of value-laden statements made by their teachers.
\end{abstract}

Keywords: climate change, environmental education, science, statements, sustainable development, value-laden

\section{Introduction}

Human survival is tied to our relationship with the natural environment. Over recent decades, humanity has benefited from development, which has enriched human lives, but has also caused unprecedented environmental change. "There is a strong, credible body of evidence, based on multiple lines of research, documenting that climate is changing and that these changes are in large part caused by human activities" (ACC, 2010, 21-22). The Learning and Skills Council (2005) argues in its Strategy for Sustainable Development that "we are living in an unsustainable world" not least because "global temperatures are rising faster than previously recorded" (Learning and Skills Council, 2005, p.4). Schultz (2002) emphasized that it is essential to establish a sustainable lifestyle that depends on a balance between the consumption of individuals and the capacity of the natural environment for renewal. Sustainable development is a multi-dimensional concept interpreted in many ways. Most commonly as: "development that meets the needs of the present without compromising the ability of future generations to meet their own needs" (WCED, 1987, p.43). 
Selby (2007) wrote that the foundation environmental education stands on is the position that knowledge is socially constructed, that there are cognitive, economic, moral and philosophical aspects to be considered and that there are no certainties in either theory or practice. No science teaching can avoid communicating messages about how we humans look upon and treat nature (Korfiatis, 2005). In 1975, an international United Nations Educational, Scientific, and Cultural Organization (UNESCO) workshop in Belgrade produced a statement of environmental education aims (Clayton \& Myers, 2009, p.3): "The goal of environmental education is to develop a world population that is aware of, and concerned about, the environment and its associated problems, and which has the knowledge, skills, attitudes, motivations, and commitment to work individually and collectively toward solutions to current problems and prevention of new ones." Palmer (1995) wrote that understanding the way learning occurs and what stimulates environmental behaviours is as important as environmental information. Clayton \& Myers (2009) emphasised that the success of environmental education depends particularly on cognitive development and environmental knowledge (with special attention to knowledge of biology and ecology), affective and motivational factors (especially a connection to nature and feelings about one's ability to achieve effects in the world), and actual behaviour (participating, taking action and problem-solving).

If environmental education is meant to help children find a more sustainable lifestyle, then those responsible for this must know the types of learning experiences that help produce active and informed minds (Palmer \& Neal, 1994). Research has shown that the two most frequently cited socialisers of children's pro-environmental behaviour are the family and teachers (Chawla, 2009; Duarte et al., 2015; Torkar, 2014) it is vital that teachers equip students with the best sources of information to enable them to make reasoned decisions about the environment and other socioeconomic issues that will confront them. Torkar (2014) investigated Slovene preschool and elementary school teachers' views on teaching practices important for environmental education. Teachers emphasized direct experiences in nature, discussions about environmental problems, active participation of students in environmental activities and the importance of teachers as role models. Teachers are or should be aware of social pressures on them to be model citizens and that their actions help establish the next generation's moral compass (Jacobson et al., 2006). "Live what you teach \& teach what you live" is a principle which implies that people should behave in accordance with the values they teach (Torkar, 2013). Mulder (2010) presents the results of a survey among international sustainable development teachers in engineering, engineers and engineering students on the acceptability of value-laden statements. Sustainable development teachers in engineering were more critical about the value-laden statements than their students and professional engineers. Mulder concluded that "teachers should help students identifying normative issues in work that seems to be of a technical nature and should help students in building up their own argument in these cases" (p. 83). Similarly, Torkar (2014) investigated opinions of Slovene pre-service and in-service students of preschool education and students of environmental sciences on the acceptability of value-laden statements made by teachers on issues of sustainable development and climate change. The results show that the students expect their teachers to promote the principles of sustainable development and climate change. 
In the paper that follows, we identify teachers' value-laden statements about sustainable development and climate change that are (not) acceptable for pre-service students of preschool education (non-science majors) and student teachers of biology and chemistry (science majors) in their final year of university studies at the Faculty of Education, University of Prishtina, Kosovo. The aim of the study was also to know how students' disagreements with value-laden statements are discussed in the classroom. Therefore, students' willingness to express their disagreement with the teacher's value-laden statements in the classroom was investigated. The school system and environmental education in Kosovo are outlined to present the current situation in the field which has an impact on students' views on the issues being discussed in this paper.

\section{Environmental Education in Kosovo}

The education system in Kosovo has a long history of inseparability with difficult and heavy developments of separation of the former Yugoslav federation. Kosovo is the last one that after a bloody war 1998-99 became first as a UN interim administered territory, and declared independence in 2008. Since 1999, the education in Kosovo is provided in Albanian, Bosnian, and Turkish. However, in parallel, there is also the education in Serbian language which recognizes the authority of Serbia and covers education in Serbian populated cities and villages. Unfortunately, there are still many obstacles to reform which have to be tackled. The education system is often teacher-centred, and little emphasis is placed on the development of critical thinking skills. The new curriculum is more student-centred but still is in very juvenile stages of implementation (Hyseni, Korca \& Lindemann-Mathies, 2014).

The education system in Kosovo encompasses: pre-school education (children aged 0-3 and 4-5) and pre-primary grade 0 for children ages 5-6; pre-university education comprises children aged 6-18 attending one of the education levels: primary school (children aged 6-11 in grades 1-5), lower secondary school (aged 11-15 in grades 6-9) and upper secondary school (aged 15-18 in grades 10-12). Compulsory education, based on Law on pre-university education Nr. 04/L32 extends from primary grades 1-9 or children aged between 6 and 15 years of age. Kosovo in 2011 approved new Curriculum Framework and in 2012 three Core Curricula covering levels according to International Standard Classification of Education- ISCED 1 (primary education), 2 (lower secondary school) and 3 (upper secondary school). One of the 6 goals of the pre-university education according to the New Curriculum is the development of responsibilities of students towards themselves, others and the environment.

Environmental problems in Kosovo have accumulated over last decades of 20-th century as a consequence of the uncontrolled use of natural resources, a growing industrial and energy production with a high level of pollution and a lack of appropriate policies, laws, and institutions which could treat and solve the problems. As a result, the environment in Kosovo has been degraded, and severe negative impacts on the health of the human population have already occurred. However, the public's knowledge about ways to encounter environmental problems is currently very limited (LindemannMatthies \& Hyseni, 2009). Educational approaches which enable people in Kosovo to deal with environmental issues in a participatory and democratic way are urgently 
needed, both in formal and informal education (Hyseni, Korca \& Lindemann-Mathies, 2014).

Kosovo, together with the rest of the world, joined the initiatives of the United Nations Decade for Education for Sustainable Development (2005- 2014) and introduced very initial steps towards an increased level of education for sustainable development that in Kosovo is often referred as environmental education (Veselaj \& Krasniqi, 2014).

While environmental education has its focus on the preservation of the natural environment and the reduction of human negative impacts, education for sustainable development wants to teach awareness, skills, perspectives, and values that will guide and motivate people to pursue sustainable livelihoods, participate in a democratic society, and live in a sustainable manner.

In other words, environmental education has its focus on problem-solving, whereas education for sustainable development is focused around capacity-building (Gough, 2006).

In many European countries, environmental education is now seen as part of education for sustainable development which implies a process-oriented, participatory, and actionoriented learning approach. Education for sustainable development is thus centered far more on humans than environmental education, and it has even been feared that since environmental education is becoming a part of education for sustainable development it would lose some of its uniqueness, i.e. the underlying worldview that humans are part of nature (McKeown \& Hopkins, 2007).

The New Kosovo Curriculum is competency based approach. In the very beginning, the Curriculum stresses the need to support students in developing responsibility for themselves, others and for the environment (Veselaj, Qirjo \& Krasniqi, 2012). Life in 21 $1^{\text {st }}$ century requires competencies to be able to cope with unpredictable circumstances and challenges, as well as capacities to make use of opportunities for personal and social progress, as well as to improve the environment (Veselaj \& Krasniqi, 2014). There are six main curricular competencies set in the Curriculum and one of them is the competency for life, work and environment by ensuring useful support for their personal life, for the society and the environment. This competency implies the engagement of every individual in protecting and developing the environment at every educational level. The Curriculum is organized in six curriculum fields and one of them is Society and environment. Through this curricular field, students develop knowledge, skills and attitudes that are essential for developing a democratic society. Students can develop an understanding of their own environment and beyond, promoting active participation and contribution toward the local, national, and global community in which they live and become committed to the social and environmental issues. One of the cross-curricular topics within the field is the education for the sustainable development covering economy, service to the community, protection of the human and natural environment and development of ecological attitudes (Veselaj \& Krasniqi, 2014).

However, upper secondary education in Kosovo is far from fulfilling the set goals of ESD, although a competency-based approach may find support from dedicated teachers. Currently, the National Curriculum of Kosovo does not include specialized courses on environmental education. Only one schoolbook focuses solely on environmental topics (for 6-graders; titled "Ecology and Environment"). 
Environmental issues in Kosovo curricula were most often included in biology, chemistry, geography and civic education curricula for grades 10 and 12 (optional upper secondary education), whereas they were almost lacking at primary-school level. Only 13 out of 130 school textbooks, most of them for biology teaching, included environmental issues. Most environmental teaching units provided students with mere information (85\%); only $15 \%$ had a different approach. They aimed to raise students' awareness of environmental values, critically reflected links between the natural, social, and cultural environment, and demonstrated the importance of a healthy environment for human health, quality of life, and sustainable development. They were most prominent in books for civic education. No environmental unit promoted students' action competence. (Hyseni, Korca \& Lindemann-Mathies, 2014).

\section{Method}

The survey was carried out in 2015. A questionnaire was completed by 63 respondents from two bachelor study programs of the Faculty of Education, University of Prishtina in Kosovo: 24 students of Biology-Chemistry Teacher (BC) program in their last year of study ( $7^{\text {th }}$ Semester) and 39 Preschool education students (PS) in their last year of ( $7^{\text {th }}$ Semester). The questionnaire for the research is used the same by used Torkar (2013), translated in Albanian language with a short explanation of concepts of sustainable development and climate changes. Students of PS program gain 40 ECTS in science courses (natural sciences, math, social sciences and environmental sciences) out of 240 ECTS. Students of BC program, which will be teaching school subjects of Biology and Chemistry after graduation, gain 140 ECTS out of 240 ECTS in science courses; including 80 ECTS in Biology and 60 ECTS in Chemistry (Veselaj, 2012; Veselaj \& Worth, 2012). Selection of science and non science teacher students is made to compare science workload of students during studies in understanding concepts of sustainable development and climate changes, how they react about when they potentially hear those teacher statements and prepare them for not only teaching but also living with idea of sustainability principles and fighting climate changes starting from personal behaviour. In the lower secondary school level in Kosovo environmental subjects mostly are taught by Biology and Chemistry teachers and in very limited cases from other scientific fields. Non science teachers also have to deal with environment and sustainable development under the curricular field Society and environment starting with kindergartens as requested with new Kosovo Curriculum. More details concerning the sample are presented in Table 1.

Table 1. Sample details

\begin{tabular}{|l|l|l|l|}
\hline \multicolumn{2}{|c|}{} & BC students & PS students \\
\hline \multirow{3}{*}{ Gender } & Male & 8 & 0 \\
\cline { 2 - 4 } & Female & 24 & 39 \\
\hline \multirow{4}{*}{ Age } & Average & 21.3 & 25.7 \\
\cline { 2 - 4 } & Min. & 20 & 21 \\
\cline { 2 - 4 } & Max. & 28 & 41 \\
\hline
\end{tabular}




\section{Research design}

Participating students from preschool education completed the questionnaire after the completion of natural sciences course and before lecturing Child and its environment course. They were in their fourth year of a four-year study programme. Participating students from Biology-Chemistry program were in their last (fourth year) year of the study programme. They completed the questionnaires before environmental pollution and protection course session.

The questionnaire consisted of 15 value-laden statements focused on three important dimensions: (1) ecological, social and economical dimensions of SD, (2) developeddeveloping countries, and (3) climate changes. Questions were taken from questionnaires developed by Mulder (2010) and Torkar (2013). For each given value-laden statement students had to choose among options "acceptable statement", "unacceptable statement" and "cannot decide". Students were also asked how they reacted to unacceptable statements of their professors. Students needed on average 10 minutes to answer the questions.

Descriptive analysis of the data was done. The differences between groups of students were tested using the chi-square statistics. Students' views on the acceptability of valueladen statements and their respond when hearing them was also compared (Fig.1).

\section{Results}

In Table 2 and Table 3 the results for the two groups of students are presented separately and in total. Overall, more than ninety percent of students found teacher's statement that calls for opposition toward the government that would not lead us to sustainable development to be acceptable. Two-thirds of students found the statement where teachers do not care for SD not to be acceptable.

Table 2. Value-laden statements made by teachers on issues of sustainable development (SD) and their acceptability for PS students and BC students.

\begin{tabular}{|c|c|c|c|c|c|c|c|}
\hline \multirow[t]{2}{*}{ Teacher's statement } & \multirow[t]{2}{*}{ Sample } & \multicolumn{2}{|c|}{ Acceptable } & \multicolumn{2}{|c|}{ Unacceptable } & \multicolumn{2}{|c|}{ Neutral } \\
\hline & & f & $\%$ & $f$ & $\%$ & f & $\%$ \\
\hline \multirow{3}{*}{$\begin{array}{l}\text { 1. I do not care about SD; I just } \\
\text { make a living teaching it!* }\end{array}$} & PS & 8 & 20.5 & 21 & 53.8 & 10 & 25.6 \\
\hline & $\mathrm{BC}$ & 3 & 12.5 & 20 & 83.3 & 1 & 4.2 \\
\hline & Total & 11 & 17.5 & 41 & 65.0 & 11 & 17.5 \\
\hline \multirow{3}{*}{$\begin{array}{l}\text { 2. We have to fight against a } \\
\text { government that does not support } \\
\text { SD. }\end{array}$} & PS & 35 & 89.7 & 0 & 0 & 4 & 10.3 \\
\hline & $\mathrm{BC}$ & 22 & 91.7 & 1 & 4.2 & 1 & 4.2 \\
\hline & Total & 57 & 90.5 & 1 & 1.6 & 5 & 7.9 \\
\hline \multirow{3}{*}{$\begin{array}{l}\text { 3. Child labor is intolerable in all } \\
\text { countries of the world.* }\end{array}$} & PS & 18 & 46.2 & 20 & 51.3 & 1 & 2.6 \\
\hline & $\mathrm{BC}$ & 13 & 54.2 & 5 & 20.8 & 6 & 25 \\
\hline & Total & 31 & 49.2 & 25 & 39.7 & 7 & 11.1 \\
\hline \multirow{3}{*}{$\begin{array}{l}\text { 4. Developed countries should be } \\
\text { responsible for eradication of poverty } \\
\text { in underdeveloped and developing } \\
\text { countries.* }\end{array}$} & PS & 35 & 89.7 & 1 & 2.6 & 3 & 7.7 \\
\hline & $\mathrm{BC}$ & 14 & 58.3 & 4 & 16.7 & 6 & 25 \\
\hline & Total & 49 & 77.8 & 5 & 7.9 & 9 & 14.3 \\
\hline
\end{tabular}




\begin{tabular}{|c|c|c|c|c|c|c|c|}
\hline \multirow{3}{*}{$\begin{array}{l}\text { 5. SD means stabilization of } \\
\text { population numbers; therefore, we } \\
\text { need family planning programs. }\end{array}$} & PS & 25 & 65.8 & 6 & 15.8 & 7 & 18.4 \\
\hline & $\mathrm{BC}$ & 17 & 70.8 & 5 & 20.8 & 2 & 8.3 \\
\hline & Total & 42 & 67.8 & 11 & 17.7 & 9 & 14.5 \\
\hline \multirow{3}{*}{$\begin{array}{l}\text { 6. Developed countries have a } \\
\text { responsibility to support SD in } \\
\text { developing countries. }\end{array}$} & PS & 28 & 71.8 & 3 & 7.7 & 8 & 20.5 \\
\hline & $\mathrm{BC}$ & 15 & 62.5 & 5 & 20.8 & 4 & 16.7 \\
\hline & Total & 43 & 68.3 & 8 & 12.7 & 12 & 19.0 \\
\hline \multirow{3}{*}{$\begin{array}{l}\text { 7. Developed countries should do } \\
\text { more to close their borders to } \\
\text { economic migrants from Africa and } \\
\text { Asia. }\end{array}$} & PS & 6 & 15.4 & 24 & 61.5 & 9 & 23.1 \\
\hline & $\mathrm{BC}$ & 0 & 0 & 17 & 70.8 & 7 & 29.2 \\
\hline & Total & 6 & 9.5 & 41 & 65.0 & 16 & 25.5 \\
\hline \multirow{3}{*}{$\begin{array}{l}\text { 8. Everybody should become a } \\
\text { vegetarian. }\end{array}$} & PS & 0 & 0 & 32 & 82.1 & 7 & 17.9 \\
\hline & $\mathrm{BC}$ & 0 & 0 & 20 & 83.3 & 4 & 16.7 \\
\hline & Total & 0 & 0 & 52 & 82.5 & 11 & 17.5 \\
\hline \multirow{3}{*}{$\begin{array}{l}\text { 9. There is nothing wrong with killing } \\
\text { whales. }\end{array}$} & PS & 3 & 7.7 & 24 & 61.5 & 12 & 30.8 \\
\hline & $\mathrm{BC}$ & 1 & 4.2 & 19 & 79.2 & 4 & 16.7 \\
\hline & Total & 4 & 6.3 & 43 & 68.3 & 16 & 25.4 \\
\hline \multirow{3}{*}{$\begin{array}{l}\text { 10. All people on the planet should } \\
\text { have equal rights to access natural } \\
\text { resources like oil and natural gas. }\end{array}$} & PS & 25 & 64.1 & 6 & 15.4 & 8 & 20.5 \\
\hline & $\mathrm{BC}$ & 15 & 62.5 & 1 & 4.2 & 8 & 33.3 \\
\hline & Total & 40 & 63.5 & 7 & 11.1 & 16 & 25.4 \\
\hline \multirow{3}{*}{$\begin{array}{l}\text { 11. As long my teaching salary is so } \\
\text { low, I am not going to advocate SD. }\end{array}$} & PS & 7 & 18.4 & 24 & 63.2 & 7 & 18.4 \\
\hline & $\mathrm{BC}$ & 1 & 4.2 & 14 & 58.3 & 9 & 37.5 \\
\hline & Total & 8 & 12.9 & 38 & 61.3 & 16 & 25.8 \\
\hline
\end{tabular}

*The result of the chi-square statistic are significant at $p<.05$.

Eighty percent of students found statement that developed countries should be responsible for the eradication of poverty in underdeveloped and developing countries to be acceptable. Seventy percent of students found family planning policy that would control the number of births and stabilise the population on the planet to be acceptable. There was almost nobody who would accept teacher's statement that there is nothing wrong with killing whales. Two-thirds of the students found teacher's statement supporting global equity of access to natural resources to be acceptable. More than twothirds of the students found teacher's statement about the responsibility of developed countries to promote sustainable development in developing countries to be acceptable. Fifty percent of the students accepted teachers' statement that child labour is intolerable in all countries of the world. Only ten percent of students found teacher's statement that developed countries should do more to close their borders to economic migrants from Africa and Asia to be acceptable. Similarly, ten percent of students would not mind if a teacher would not advocate SD because teaching salary is too low. Nobody found acceptable the teacher's statement that everybody should become a vegetarian.

Results in Table 3 show that majority of students considered any teacher's statement that would throw doubt about the cause or necessity to act against climate change to 
be unacceptable. More than one-third of students found teacher's statement that would consider climate change in a positive way, because some areas could, as a result, have a warmer climate and lower bills for heating to be acceptable. Sixty percent of students found the statement that climate change is punishment sent from God (the term used as such in three religions living in Kosovo: Muslims, Catholics and Orthodox) and we must pay for our sins to be unacceptable. Almost half of students found to be unacceptable the statement that humans are not a cause of climate changes; therefore, there is no need for action. Two third of students also found the statement that climate change was made up to sell eco-products to be unacceptable.

Table 3. Value-laden statements made by teachers on issues of climate change (CC) and their acceptability for PS students and BC students.

\begin{tabular}{|c|c|c|c|c|c|c|c|}
\hline \multirow{2}{*}{ Teacher's statement } & \multirow[t]{2}{*}{ Sample } & \multicolumn{2}{|c|}{ Acceptable } & \multicolumn{2}{|c|}{ Unacceptable } & \multicolumn{2}{|c|}{ Neutral } \\
\hline & & $\mathrm{f}$ & $\%$ & $f$ & $\%$ & $f$ & $\%$ \\
\hline \multirow{3}{*}{$\begin{array}{l}\text { 12. CC is not caused by humans, so } \\
\text { we need not reduce CO2 emissions. }\end{array}$} & PS & 12 & 13.8 & 16 & 41 & 11 & 28.2 \\
\hline & $\mathrm{BC}$ & 3 & 12.5 & 14 & 58.3 & 7 & 29.2 \\
\hline & Total & 15 & 23.8 & 30 & 47.6 & 18 & 28.6 \\
\hline \multirow{3}{*}{$\begin{array}{l}\text { 13. CC is positive because it brings to } \\
\text { some areas of the world a warmer } \\
\text { climate and lower bills for the } \\
\text { heating. }\end{array}$} & PS & 14 & 36.8 & 12 & 31.6 & 12 & 31.6 \\
\hline & $\mathrm{BC}$ & 9 & 37.5 & 8 & 33.3 & 7 & 29.2 \\
\hline & Total & 23 & 37.1 & 20 & 32.2 & 19 & 30.7 \\
\hline \multirow{3}{*}{$\begin{array}{l}\text { 14. CC is punishment sent from } \\
\text { God and we must pay for our sins. }\end{array}$} & PS & 3 & 7.7 & 24 & 61.5 & 12 & 30.8 \\
\hline & $\mathrm{BC}$ & 4 & 16.7 & 13 & 54.2 & 7 & 29.2 \\
\hline & Total & 7 & 11.1 & 37 & 58.7 & 19 & 30.2 \\
\hline \multirow{3}{*}{$\begin{array}{l}\text { 15. CC was made up by those who } \\
\text { want to sell us expensive eco- } \\
\text { products. }\end{array}$} & PS & 0 & 0 & 23 & 59 & 16 & 41 \\
\hline & $\mathrm{BC}$ & 2 & 8.3 & 16 & 66.7 & 6 & 25 \\
\hline & Total & 2 & 3.2 & 39 & 61.9 & 22 & 34.9 \\
\hline
\end{tabular}

Both groups of students found teacher's statements that would put a shadow of doubt on the need for sustainable development or climate change issues to be unacceptable. However, there were significant differences between the groups in three statements. There was a significant difference in their view on the acceptability of the statement that teachers do not care for sustainable development but they just make a living teaching it. $\mathrm{BC}$ students found this statement significantly more unacceptable $\left(\chi^{2}=6.4553, p=.039\right)$. BC students found teacher's statement that developed countries should be responsible for the eradication of poverty in underdeveloped and developing countries to be less acceptable than PS students $\left(\chi^{2}=8.7231, p=.013\right)$. PS students found teachers' statement that child labour is intolerable in all countries of the world more unacceptable while BC students expressed a more neutral position towards the statement $\left(\chi^{2}=\right.$ 10.3958, $p=.006)$.

Students were asked to describe their reactions to unacceptable value-laden statements in case these are made by their teacher (Figure 1). Most of the students would become alerted and discuss the statement with a colleague(s) in the classroom. Differences 
between the groups were not significant. Six students had not heard unacceptable statements until now.

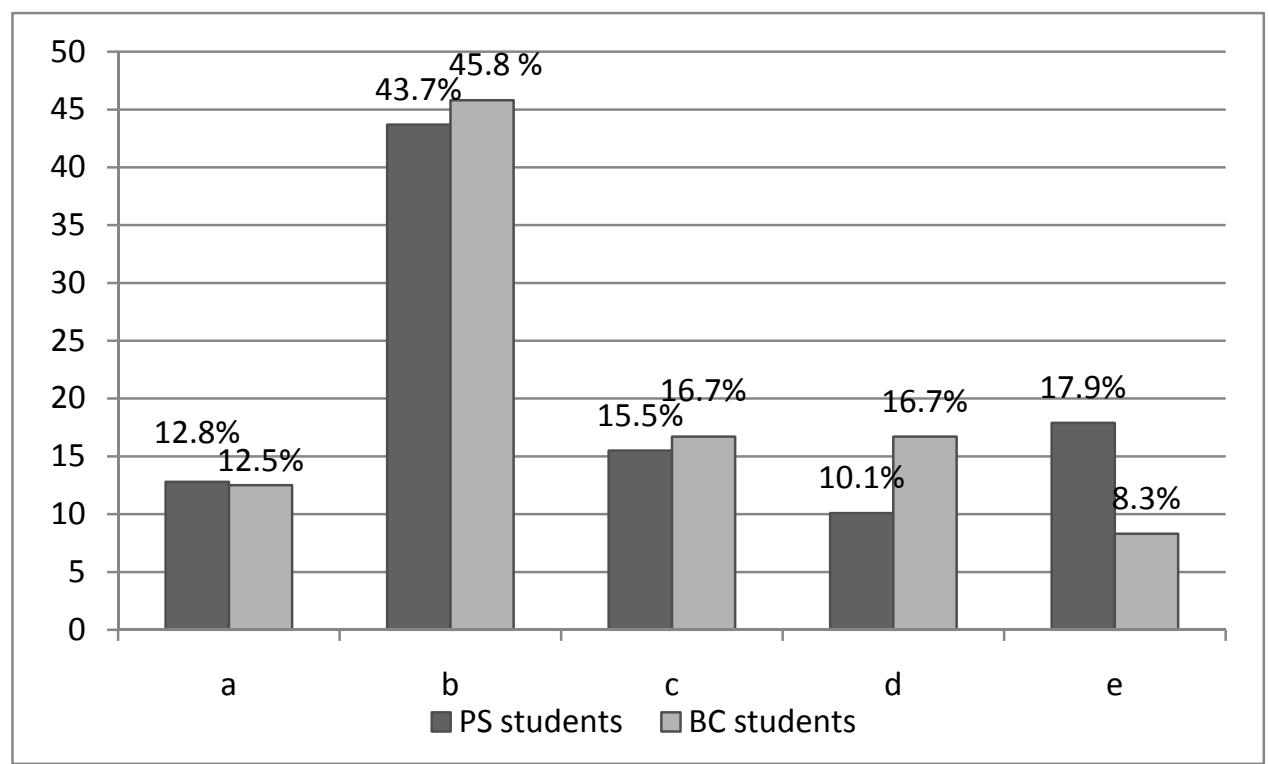

Figure 1. Student's reaction to unacceptable value-laden statements made by their teachers.

Legend (Figure 1):

$a-I$ remain quiet, $b-I$ become alerted and mention my concerns to colleague(s), $c-I$ publicly express my disagreement and discuss it in the classroom, $d-I$ privately discuss my concerns with the teacher, $e$ - I have not yet beard any unacceptable statements until now.

\section{Discussion and conclusions}

The first aim of the study was to investigate students' views on the acceptability of teacher's value related statements about sustainability and climate change. Overall, the majority of students found teacher's carelessness about sustainable development or climate change unacceptable. Results show that students expect their teachers to promote the principles of sustainable development, which confirms the findings of previous studies (Jacobson et al., 2006; Mulder, 2010; Torkar, 2013).

However, some students' views on the acceptability of teacher's statements were contrary to our expectations and findings of previous studies conducted in other countries. Both groups of students found teacher's statements that would put a shadow of doubt on the need for sustainable development or climate change issues to be unacceptable. BC students found the teacher's statement where teachers do not care for sustainable development but they just make a living by teaching it, significantly more unacceptable. This may be connected with their deeper scientific knowledge and competencies in the field of science or because of their future role to educate about the environment and sustainable development. They also found teacher's statement that developed countries should be responsible for the eradication of poverty in underdeveloped and developing countries to be less acceptable than PS students. This 
survey was conducted not far after the period of massive flee of Kosovar`s (end of 2014, beginning of 2015), where within a few months, thousands of mostly young people and families left Kosovo in search of better opportunities in the EU countries (mainly in Germany, France, Scandinavian countries etc.) because of unemployment and poverty in their homeland. At this point half of million diaspora Kosovars are living in developed countries without any plans to return. Students see responsibility but also possibility of developed countries to help developing countries in sustainable development. As a consequence, the majority of students showed opposition or neutral position towards the statement that developed countries should do more to close their borders to economic migrants from Africa and Asia, however, these results are not surprising because there are many economic migrants from Kosovo too.

Surprisingly, only half of the students found the statement that child labor is intolerable in all countries of the world as acceptable. PS students found teachers' statement that child labour is intolerable in all countries of the world more unacceptable while BC students expressed a more neutral position towards the statement. This result seems to be connected with a certain tradition in Kosovo where children work to help their families: children herding the cows, girls helping in the household, boys and girls working in the fields (UNICEF, 2004).

An interesting finding is that two-thirds of the students found the teacher's statement that there is nothing wrong with killing whales, unacceptable while the rest of students mainly neutral. This is an indication of students' biocentric ethics - considering other, non-human, forms of life as valuable (Rolston, 1995). This, in fact, means that they extend intrinsic value to at least some non-human living beings, like whales, and that they do not see in them only instrumental value.

Most of the students reported that they already heard unacceptable value-laden statements made by their teacher. Their most common reaction was to become alerted and discuss the statement with a colleague(s) in the classroom. The majority of students were not ready to express their opinion publicly and/or oppose the teacher's statement. This might be partly connected with the cultural background and political history in this part of Europe. Kosovo used to be a part of the former Yugoslavia, where in socialistic times public (collective) participation in decision making was not always appreciated. Torkar (2014) emphasized that teacher's low awareness of the importance of active participation by students in environmental education may be at least partially attributed to their own experience with active participation. Being raised in a Slovenian society, where democratic decision-making system was uncommon in the past (post-communist country), the importance of active participation in community issues was not perceived as relevant and, therefore, not encouraged among students. This could also be the case for Kosovo. In order to protect the environment from unwanted changes, public awareness is one of the crucial transitions in the society.

To conclude, the findings of this study do not provide clear answers on how science education of science and non-science major students influence on their acceptance of value-laden statements made by their teachers. Therefore, further studies are necessary to unveil the impact of other personal, social, cultural and economic factors influencing student's attitudes toward sustainability and climate change issues. 


\section{References}

America's Climate Choices (ACC): Panel on Advancing the Science of Climate Change; National Research Council. 2010. Advancing the Science of Climate Change. Washington, D.C.: The National Academies Press.

Chawla, L. 2009. Growing up green: Becoming an agent of care for the natural world. The Journal of Developmental Processes, 4 (1), 6-23.

Clayton, S., \& Myers, G. 2009. Conservation Psychology: understanding and promoting human care for nature. Wiley-Blackwell, Chichester,

Duarte, R., Escario, J.J.\& Sanagustín, M-V. (2015). The influence of the family, the school, and the group on the environmental attitudes of European students. Environmental Education Research, 1-20, DOI:10.1080/13504622.2015.1074660.

Gough, A. 2006. Sustainable schools in the UN decade of education for sustainable development: Meeting the challenge. Southern African Journal of Environmental Education, 23, 48-63.

Hyseni, M., Korca, B., Lindemann-Mathies, P. 2014. Environmental Education in High Schools in Kosovo-A teachers' perspective. International Journal of Science Education, 36 (16), 2750-2771.

Jacobson, S. K., McDuff, M. D., \& Monroe, M. C. 2006. Conservation education and outreach techniques. New York: Oxford University Press, Inc.

Korfiatis K.J. 2005. Environmental education and the science of ecology: exploration of an uneasy relationship. Environmental Education Research, 11(2), 235-248.

Learning and Skills Council. 2005. From Here to Sustainability: The Learning and Skills Council's Strategy for Sustainable Development, September, LSC, Coventry

Lindemann-Matthies, P., \& Hyseni, M. 2009. Perception of and knowledge about biodiversity by stakeholders and laypersons in Kosovo. Journal of International Environmental Application and Science, 4, 413-427.

McKeown, R., \& Hopkins, C. A. 2007. Moving beyond the EE and ESD disciplinary debate in formal education. Journal of Education for Sustainable Development, 1, 17-26.

Mulder, K.F. 2010. Don't preach. Practice! Value laden statements in academic sustainability education. International Journal of Sustainability in Higher Education, 11(1), 74-85.

Palmer, J. 1995. Influences of pro-environmental practices. In: J. Palmer, W. Goldstein, A. Curnow (Eds.), Planning education to care for the earth (pp. 3-8). Gland, Switzerland \& Cambridge: IUCN,

Palmer, J., \& Neal, P. 1994. The Handbook of Environmental Education. London: Routledge.

Rolston, H. 1995. Nature, culture, and environmental ethics. In: D. Ogrin (Ed.), Nature conservation outside protected areas (pp. 25-33). Ljubljana: Ministrstvo za okolje in prostor.

Selby, D. 2007. As the heating happens: Education for Sustainable Development or Education for Sustainable Contraction? International Journal of Innovation and Sustainable Development, 2 (34), 249-267.

Schultz, W.P. 2002. Inclusion with Nature: The Psychology Of Human-Nature. In: P. Schmuck, \& P. W. Schultz (Eds.), The psychology of sustainable development (pp. 61-78). New York: Kluwer.

Torkar, G. 2014. Learning experiences that produce environmentally active and informed minds. NJAS Wageningen Journal of Life Sciences, 69, 49-55.

Torkar, G. 2013. Live What You Teach \& Teach What You Live: Student Views on the Acceptability of Teachers' Value-Related Statements about Sustainability and Climate Change. CEPS Journal, 3(1), 45-58.

UNICEF 2004. Child labor in Kosovo- a study on working children, http://www.unicef.org/kosovoprogramme/kosovo_media_pub_prot.008.04.pdf (retrieved May 02, 2016)

Veselaj, Z. \& Krasniqi, Z. 2014. Mapping of education for sustainable development in the new curriculum of Kosovo and challenges of implementation. Proceedings of SGEM Conference Vol. 1, p. 803-810 ISBN 978-619-7105-22-3 ISSN 2367-5659, DOI 10.5593/sgemsocial 2014B11.

Veselaj, Z., \& Worth, M. 2012. The program content of teacher education in the public universities in the Republic of Kosovo. Book of abstracts. Albania International Conference on Education, Tirana, p. 51.

Veselaj, Z. 2012. Mapping of the Educational Program's of Public Universities in Kosovo, A publication under EU IPA 2009 funded Project “ IPA-Teacher training and capacity building for school directors in Kosovo", p. 20. 
Veselaj Z., Qirjo M., \& Krasniqi Z. 2012. Children as a promoter of environmental education and awareness in transitional societies- Case of Kosovo. Proceedings of "Week of Science in Kosovo" 543-547.

World Commission on Environment and Development (WCED), 1987. Our Common Future. Oxford: Oxford University Press. 